\title{
Rainfall influence on species composition of the ciliate community inhabiting bromeliad phytotelmata
}

\author{
Paulo Roberto Bressan Buosi ${ }^{1 *}$, Laura Roberta Pinto Utz² , Bianca Ramos de Meira ${ }^{1}$, Bianca Trevizan Segóvia da Silva ${ }^{1}$, \\ Fernando Miranda Lansac-Tôha', Fabio Amodeo Lansac-Tôha' and Luiz Felipe Machado Velho
}

\begin{abstract}
Background: In this paper, we verified the changes in species composition of the ciliate community inhabiting phytotelmata of tank bromeliads in response to seasonality (rainfall). Plants were located at several heights of a great rocky wall on the left bank of the Parana River, southern Brazil. We also assessed if the heights of the plants in relation to the river influence the ciliate species composition. Thus, samplings were performed in the dry and rainy seasons, in three layers of the rock walls (lower, middle, and upper), with a total of 72 samples in both periods.

Results: A relative high number of species and a predominance of hymenostomatids were observed in the sampled plants. Among the recorded species, about 35\% occurred exclusively in the dry season. The detrended correspondence analysis demonstrated that the ciliate community changed substantially due to rainfall. However, there was no distinctness in species composition among the strata. In contrast to expectations, the number of species recorded in the dry season was greater than that recorded in the rainy season, refuting the hypothesis that the precipitation volume favors an increase in the number of species.

Conclusions: The rainfall is, undoubtedly, the main factor structuring the community and determining the ciliate species composition in the phytotelmata of the bromeliads. We found that the closeness of the plants with the river is also an important factor for the structuration of the community, due to the dispersion of organisms from the river to the tanks. The occurrence and predominance of planktonic species in the plants at the lower stratum and soil species at the higher stratum indicates a great influence of the neighboring environments on the ciliate community inhabiting the phytotelmata.
\end{abstract}

Keywords: Ciliates; Protozoa; Seasonality; Species composition; Tank bromeliads

\section{Background}

Floodplains are environments that are strongly influenced by the annual rainfall. This fluctuation determines changes in the hydrological levels, which constitutes, in general, the main factor structuring the aquatic communities. Also, it plays an important role in the composition of communities in the transition zones between water and land, such as the riparian vegetation (Souza et al. 2004).

Several plant structures like leaves, stems, and flowers have the ability to capture and store rainwater, creating

\footnotetext{
* Correspondence: paulobuosi@hotmail.com

'Graduate Program in Ecology of Continental Aquatic Environments, Universidade Estadual de Maringá, Av. Colombo, 5790, Maringá, Paraná 87020-900, Brazil

Full list of author information is available at the end of the article
}

natural aquatic microcosms so-called phytotelmata (Fish 1983; Kitching 2000). These environments provide an excellent option for the study and understanding of ecological processes in tropical and temperate communities (Kitching 2000, 2001), in addition to serve as natural ecological models that may help understand the dynamics of aquatic communities (Srivastava et al. 2004).

In bromeliads, phytotelmata are formed by the congruence of leaf axils creating a tank, characteristic of these plants. In addition to rainwater, the bromeliad tanks also capture leaves that are decomposed and consumed by organisms. According to Frank (1983) and Kitching (2000, 2001), the richness, abundance, and species composition of communities present in phytotelmata are especially 
controlled by nutrient availability. Thereby, a phytotelma provides nutrient resources and spatial refuge for a range of species, whose interactions form a complex food web (Ngai and Srivastava 2006).

According to Kitching (2001), the presence of an organism within a particular unit of phytotelma habitat at any point in time implies two things: first, that the organism or its antecedents were able to find the habitat unit and, second, after having entered the unit, the species has been able to survive until the time in question. This author affirms that the entry of an organism in such a peculiar habitat disturbs the community as a whole, enhancing the intra- and interspecific competition and affecting the community food web. In this way, the rainfall is an important structuring factor of the communities inhabiting the phytotelmata since it promotes a decrease in competition and provides greater space and food for the species dwelling these habitats.

Physical barriers of natural microcosms represent a natural restraint to the biota, which ease the addition or removal of species in experimental studies (Srivastava et al. 2004). However, these authors emphasize that phytotelmata are not completely closed systems and that the community can be constantly changed by processes like emergence of insect larvae or colonization by microorganisms.

Bromeliads are often found growing nearby freshwater environments, like ponds, swamps, and rivers. This proximity would allow, theoretically, an exchange of species between the phytotelmata and the bodies of water. However, the species composition found in the tanks of the bromeliads seems to be rather endemic, being quite different from the aquatic fauna observed in neighboring environments (Lopez et al. 2009).

Lopez et al. (2009) stated that the distinctness in the species composition between the phytotelmata of the bromeliads and the nearby aquatic environments could be explained by the high level of specialization developed by the phytotelmic fauna throughout time. These authors affirm that the tanks of the bromeliads might suffer a 'small island effect', being unable to sustain viable populations of organisms found in larger ponds. The singular characteristics of physical and chemical factors are also considered an abiotic barrier for the establishment and development of organisms in bromeliad phytotelmata (Lopez et al. 2009).

The unique physical and chemical features of the bromeliad phytotelmata were indicated by studies that verified the release of chemical substances on the stored water in the tanks by the bromeliads' leaves (Benzing 1990). These specific substances may act as limiting factor for the establishment and development of populations that perhaps reach the phytotelma. In this way, the characteristics of the bromeliad tank water may both restrict as well as provide countless niches for several protozoa and small metazoans (Picado 1913; Maguire 1971; Azoury and Martinelli 2000; Schönborn 2003).

Since the beginning of the 20th century, researchers have been investigating the communities of the tank bromeliads and recorded several animal species such as rotifers, oligochaete, arthropods, and chordates (Picado 1912; Thienemann 1934; Inger 1966; Torales et al. 1972; Frank et al. 1976; Little and Hebert 1996; Reid and Janetsky 1996; Sodré et al. 2010; Suárez-Morales et al. 2010), as well as microbial eukaryotes such as ciliates (Picado 1912; Laessle 1961; Maguire 1971; Maguire and Belk 1967; Vandermeer et al. 1972; Foissner et al. 2003; Dunthorn et al. 2012).

Although recently, a substantial number of papers emphasizing the ecology and taxonomy of ciliates have been published (Foissner et al. 2003; Foissner and Wolf 2009; Foissner et al. 2009; Foissner 2010; Foissner and Stoeck 2011; Dunthorn et al. 2012; Sabagh et al. 2012; Foissner 2013; Weisse et al. 2013a, b), little is known about some ecological aspects of the community.

Most of the recent studies on bromeliad phytotelmata are taxonomical and have described several, possibly endemic new species. For instance, Dunthorn et al. (2012) performed a combined morphological and molecular study in which they mentioned a discovery of 45 undescribed species that might have a distribution restricted to phytotelmata. These new findings bring to light discussions about the theory of ubiquity of the microorganisms, and may refuse the idea that in the microbial world, 'everything is everywhere' (Finlay et al. 1996, 2004). In this way, it is important to direct attention on the species composition of the microbial eukaryotes communities inhabiting phytotelmata.

The aim of this study was to describe the species composition of the ciliate community associated to the tanks of the bromeliad Aechmea distichantha Lem in the riparian vegetation of the Paraná River, southern Brazil. It was also intended to assay the influence of the rainfall and the height of the plants - divided in lower, middle, and upper strata - in relation to the river, on the ciliate species composition. More specifically, three hypotheses were formulated: (i) the ciliate species composition is significantly distinct between the rainy and the dry seasons, (ii) the number of species in the rainy season will be significantly higher than that recorded in the dry season, and (iii) plants at different heights in relation to the river have specific ciliate species composition.

\section{Methods}

\section{Study area}

The Upper Paraná River floodplain is inserted within the Atlantic Forest Bioma and Semideciduous Seasonal Forest (Campos and Souza 1997). The forest formations are 
reduced to fragments close to the banks of Paraná River, on the islands, and dispersed in strands of riparian vegetation around aquatic environments of this floodplain (Campos and Souza 1997).

The study was conducted on the banks of Paraná River (Southern Brazil) with samplings on the left, steep bank in the region between Nupélia's Field Station and the district of Porto São José, municipality of São Pedro do Paraná (Figure 1). The left bank of Paraná River is characterized by hills with a convex top that provide a great elevation on this side of the river (above $500 \mathrm{~m}$ ), with several rocky walls formed by sedimentary rocks of the Cretaceous period and scarce flooding areas (Souza Filho and Stevaux 2004). These walls provide habitat suitable for colonization by several epiphytic plant species, such as the bromeliads used in this study.

Plants of $A$. distichantha can be terrestrial or epiphytic (facultative epiphyte) in deciduous or semi-deciduous forest, with wide distribution in South America, being found in forests of Southern Brazil, Bolivia, Paraguay, Uruguay, and Northern Argentina (Smith and Downs 1979). This tank bromeliad has pungent leaves about 30- to $100-\mathrm{cm}$ long and reproduces both sexually and asexually.

\section{Sampling methodology}

Individuals of $A$. distichantha were collected from the rocky walls on the left bank of the Paraná River. To evaluate the influence of proximity to the river on the ciliate species composition, we collected plants at three different strata of the rocky wall: upper, middle, and lower. The strata heights were defined in the first sampling, considering the location of the plants. The plants at the lower stratum were up to $3 \mathrm{~m}$ from the river level, those at the middle stratum, approximately from 3 to $7 \mathrm{~m}$; and those at the upper stratum more than $7 \mathrm{~m}$ above the river level (Figure 2). Regardless the variation in the river level, the range of each stratum was kept in all sampling efforts. Occasionally, some sampled plants were on the treetops.

A total of six samplings were performed in 2010, three in the dry period (February, March, and April) and other three in the rainy period (October, November, and December). At each sampling, four individuals of $A$. distichantha were taken from each stratum, totaling 72 samples.

The plants were removed manually from the wall, placed in plastic bags, and taken to Nupélia's Field Station (Porto Rico, Paraná State). In the laboratory, the water present in each plant was placed in a tray and the tank was briefly washed with distilled water to remove organisms that could be attached to the tank.

Rainfall data were provided by Nupélia's climatologic station, located near the Field Station. Only the accumulated rainfall data of the week immediately prior to the samplings was used.

\section{Laboratory analysis}

After removing the water from the plants, we measured the volume of the sample using a graduated cylinder, as well as the perimeter and height of each tank. Samples

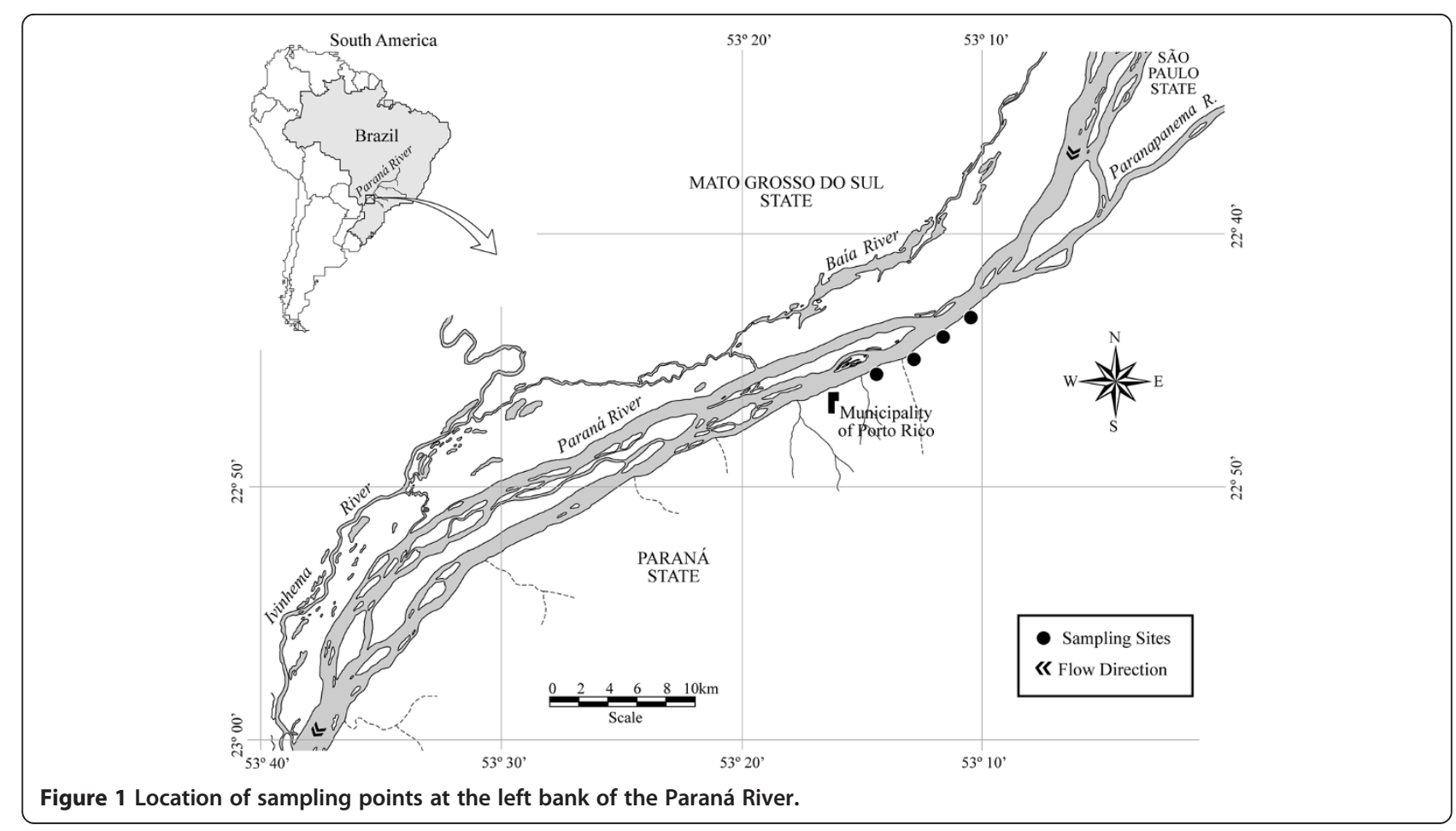




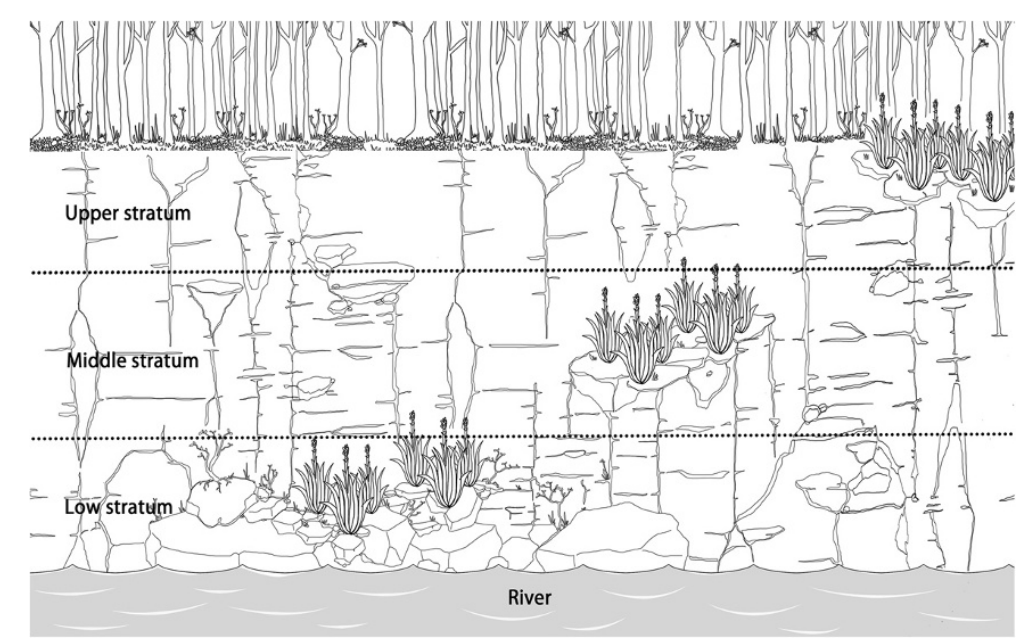

Figure 2 Rocky wall on the left bank of the Paraná River, highlighting the three-sampled strata.

were analyzed in vivo, using an optical microscope, within a maximum period of $6 \mathrm{~h}$ after sampling. Species identification was based on specialized literature (Dragesco and Dragesco-Kernéis 1986; Foissner et al. 1991, 1992, 1994, 1995, 1999, 2002; Patterson 1992; Foissner and Berger 1996), and taxonomic papers (Foissner 2003a, b, 2010; Foissner and Wolf 2009; Foissner et al. 2009; Foissner and Stoeck 2011).

For the unidentified species during the collection period, we set up culture of organisms in Petri dishes, from aliquots of live samples incremented with crushed rice grains previously sterilized.

\section{Data treatment}

The frequency of occurrence of a particular species was calculated as the percentage of samples in which the species occurs. In this way, all the recorded species were classified within four distinct groups, according to Foissner et al. (1994): euconstant species (occur in $76 \%$ to $100 \%$ of the samples), constant species (occur in $51 \%$ to $75 \%$ of the samples), accessory species (occur in $26 \%$ to $50 \%$ of the samples), and accidental species (occur in less than $26 \%$ of the samples).

To summarize the differences in species composition between the two hydrological periods among the different strata, we performed a detrended correspondence analysis (DCA, Hill and Gauch 2004), based in the presence/ absence data. The eigenvalues and the scores of the DCA axes were calculated using the software PcOrd 4.01 (McCune and Mefford 1999). Species that were found in only one sample were excluded from the procedure, due to the high influence of rare species in this analysis.

A multi-response permutation procedure (MRPP, according to Zimmerman et al. 1985) was applied to test the differences in ciliate species compositions between dry and rainy periods. This analysis was based on the presence/ absence data of species in samples of both periods. MRPP is a non-parametric procedure for testing the hypothesis of no difference between two or more groups of entities. The groups must be set a priori. A discriminant analysis is a parametric procedure that can be used on the same general kind of questions. However, MRPP has the advantage of not requiring assumptions (such as multivariate normality and homogeneity of variances) that are seldom met with ecological community data (McCune and Mefford 1999).

To estimate the ciliate species richness associated with the phytotelmata of $A$. distichantha and to analyze the expected total number of species that was recorded in our survey, we used different non-parametric extrapolating indexes based on incidence data. We used Ice, Chao2, Jacknife 1 and 2, and Bootstrap estimators, and the calculation was performed using the program EstimateS (Cowell 1997).

\section{Results \\ Rainfall data}

A total of $40 \mathrm{~mm}$ of rainfall was recorded in the weeks prior to the two collections, with 13.2 and $26.8 \mathrm{~mm}$ recorded before the first and second samplings, respectively. In February, a value of $9.4 \mathrm{~mm}$ was recorded, and in March, $0.8 \mathrm{~mm}$. April had no rainfall in the week prior to the collection. In November, a total of $3.4 \mathrm{~mm}$ of rainfall was recorded in the week prior to the sampling.

\section{Species composition}

Considering both hydrological periods, we recorded a total of 92 ciliate species, belonging to 14 different orders, associated with tanks of the bromeliad $A$. distichantha. The results of the non-parametric extrapolating indices demonstrate that the number of observed species represents from $71 \%$ to $89 \%$ of the number of species estimated by the used indices. Bootstrap (102 species) and ICE and 
Chao 2 (114 species each) were the indices that better represented the number of observed species (Figure 3).

The distribution of species among the different orders is represented in Figure 4. The order Hymenostomatida was the most representative with 18 species, followed by Hypotrichida with 12 species. Haptorida and Heterotrichida also contributed substantially for the total number of species with respectively 10 and 8 species.

All the recorded species and their frequencies of occurrence are shown in Table 1 . The majority of observed species occurred in the dry period. In this way, 40 ciliate species occurred in both periods, whereas 34 occurred exclusively in the dry period and 18 occurred exclusively in the rainy period. Regarding the spatial distinctness of the number of species (among the strata), a greater number of ciliate species was observed in the lower stratum - 76 species in both periods - among which 17 occurred exclusively in this stratum. In the middle stratum, we recorded a total of 62 species, from which 9 were found only on this stratum. The lowest number of species was found in the higher stratum (59), with only 4 being exclusive of this height. There were no significant differences in the number of species among the strata in the rainy period. In the dry period, however, the lower stratum presented a greater number of species when compared to the other two.

In relation to species frequency of occurrence, 73 were classified as accidental, 14 as accessory, 3 as constant, and 2 as euconstant. There was no single species found in all samples. However, considering both rainy and dry periods, the colpodids (order Colpodida) Colpoda steinii Maupas, 1883 and Cyrtolophosis mucicola Stokes, 1885 were the most frequent, occurring in respectively, $87 \%$ and $76 \%$ of the samples. Other colpodid species also had high frequencies, such as the supposedly endemic

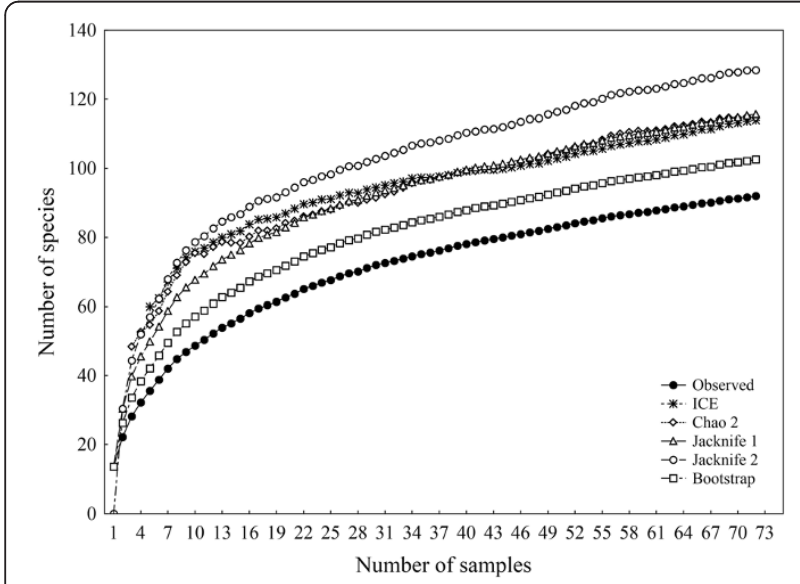

Figure 3 Results of the non-parametric extrapolating indices for the number of ciliate species associated to the tanks of the bromeliadAechmea distichantha.

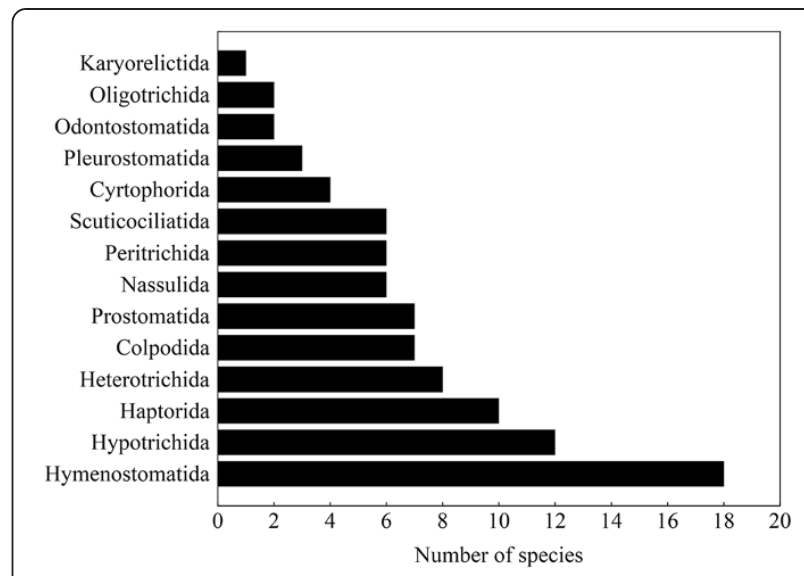

Figure 4 Number of ciliate species recorded for the different orders.

Bromeliothrix metopoides Foissner 2010, which occurred in $75 \%$ of the samples and the soil species Colpoda inflata Kahl, 1931 (62\% of the samples), and Colpoda cucculus Gmelin, 1790, which occurred in 58\% of the samples. Two recently described ciliate species, Bromeliophrya brasiliensis Foissner 2003a, b and Lambornella trichoglossa Foissner 2003a, b, both hymenostomatids and with distribution supposedly restricted to the tanks of bromeliads also had relatively high frequencies with occurrence in $68 \%$ and $51 \%$ of the samples, respectively. Further, the planktonic species Halteria grandinella Dujardin, 1841 occurred in $61 \%$ of the samples.

Considering the hydrological periods separately, in the dry period, the most frequent species were the colpodids C. steinii (86\% of the samples), B. metopoides (75\% of the samples), and C. mucicola ( $72 \%$ of the samples). In the rainy period, the species that most occurred in the samples were B. brasiliensis (89\% of the samples) and $C$. steinii (89\% of the samples). Colpoda cucullus and $C$. mucicola also presented high frequencies for this period with $81 \%$ of occurrence for each species.

The first and second axes of a detrended correspondence analysis (DCA) with eigenvalues of 0.30 and 0.21 , respectively, summarized in part the spatial and temporal variation of the species composition of the ciliate community (Figure 5A). In general, the first two axes of the DCA, based in the species presence/absence data showed a clear difference between the samples collected in the dry period, positively related with the DCA axis 1 , and the samples collected in the rainy period, negatively related with the DCA axis 1 .

In this way, the species that were positively correlated with the DCA axis 1, i.e., Caenomorpha medulusa, Campanella umbellaria, Paramecium multimicronucleatum, Euplotes sp., and Loxodes sp. characterize the dry period, while those negatively correlated with axis 1 - Aspidisca cicada, Dileptus sp., Epenardia sp., Frontonia leucas, 
Table 1 Occurrence and frequency of ciliate species recorded during both hydrological periods in the different strata

\begin{tabular}{|c|c|c|c|c|c|c|c|c|c|}
\hline \multirow[t]{2}{*}{ Order } & & \multicolumn{3}{|c|}{ Dry season } & \multicolumn{5}{|c|}{ Rainy season } \\
\hline & & Low & Mid & Upp & Low & Mid & Upp & Freq (\%) & Cod \\
\hline \multirow[t]{7}{*}{ Colpodida } & Bromeliothrix metopoides $^{1}$ & + & + & + & + & + & + & 75 & $\mathrm{Brm}$ \\
\hline & Colpoda cucullus & & + & + & + & + & + & 58.3 & $\mathrm{Coc}$ \\
\hline & C. inflata & + & + & + & + & + & + & 62.5 & Coi \\
\hline & C. magna & + & + & + & + & + & + & 48.6 & Com \\
\hline & C. steinii & + & + & + & + & + & + & 87.5 & Cos \\
\hline & Cyrtolophosis mucicola & + & + & + & + & + & + & 76.4 & Cym \\
\hline & Platyophrya vorax & + & + & + & + & + & + & 33.3 & Plv \\
\hline \multirow[t]{4}{*}{ Cyrtophorida } & Chilodonella uncinata & & & & + & + & + & 11 & Chu \\
\hline & Chlamydonellopsis sp. & + & & & & + & + & 16.6 & Chl \\
\hline & Pseudochilodonopsis algivora & + & + & + & + & + & + & 9.8 & Psa \\
\hline & Trochilioides recta & + & & + & + & + & + & 7 & Trr \\
\hline \multirow[t]{10}{*}{ Haptorida } & Didinium sp. & & & & + & & & 1.4 & - \\
\hline & Dileptus sp. & & & & & + & & 2.8 & Dil \\
\hline & Lagynophrya acuminata & & & & & + & & 1.4 & - \\
\hline & Mesodinium pulex & & + & + & & & & 2.8 & Mep \\
\hline & Monodinium sp. & + & & & & + & + & 4.2 & Mon \\
\hline & Phialina sp. & & & & & + & & 1.4 & - \\
\hline & Plagiopyla nasuta & & & & + & + & + & 9.8 & Pln \\
\hline & Spathidium sp.1 & + & & & + & + & & 5.5 & Sp1 \\
\hline & Spathidium sp.2 & & & & + & & + & 2.8 & Sp2 \\
\hline & Spathidium sp.3 & & & & + & + & + & 7 & Sp3 \\
\hline \multirow[t]{8}{*}{ Heterotrichida } & Blepharisma sp. & & & & + & + & + & 5.5 & Ble \\
\hline & Brachonella spiralis & & & + & + & + & & 8.3 & Brs \\
\hline & Caenomorpha medusula & + & & & & & & 2.8 & Cam \\
\hline & Caenomorpha sp. & + & & & & & & 1.4 & - \\
\hline & Metopus sp. & + & + & + & + & + & + & 47.2 & Met \\
\hline & Metopus striatus & + & & + & + & + & + & 4.2 & Mes \\
\hline & Spirostomum minus & + & & & & & & 4.2 & Spm \\
\hline & Stentor sp. & + & & & & & & 1.4 & - \\
\hline \multirow[t]{14}{*}{ Hymenostomatida } & Bromeliophrya brasiliensis ${ }^{2}$ & + & + & + & + & + & + & 68 & Brb \\
\hline & Colpidium colpoda & + & + & & + & + & + & 11 & Cop \\
\hline & Colpidium kleini & & & + & + & & + & 5.5 & Cok \\
\hline & Dexiostoma campylum & + & + & + & & & & 14 & Dec \\
\hline & Dexiotricha granulosa & + & & & & & & 1.4 & - \\
\hline & Epenardia sp. & & & & + & & + & 2.8 & Epe \\
\hline & Frontonia depressa & + & + & + & & + & + & 12.5 & Fra \\
\hline & F. leucas & & & & & + & + & 8.3 & $\mathrm{Frl}$ \\
\hline & Glaucoma reniforme & + & & + & & & + & 7 & Glr \\
\hline & G. scintillans & + & + & & + & + & & 5.5 & Gls \\
\hline & Lambornella trichoglossa ${ }^{3}$ & + & + & + & + & + & + & 51.4 & Lat \\
\hline & Lembadion bullinum & + & & & & & & 1.4 & - \\
\hline & L. lucens & & & & & + & & 1.4 & - \\
\hline & Paramecium multimicronucleatum & + & & & + & & & 9.8 & $\mathrm{Pac}$ \\
\hline
\end{tabular}


Table 1 Occurrence and frequency of ciliate species recorded during both hydrological periods in the different strata (Continued)

\begin{tabular}{|c|c|c|c|c|c|c|c|c|c|}
\hline & P. putrinum & + & & & & & & 1.4 & - \\
\hline & Philasterides armatus & + & + & + & & & & 9.8 & Pha \\
\hline & Tetrahymena sp. & + & + & & + & + & & 29.2 & Tet \\
\hline & Urocentrum turbo & + & & + & & & & 12.5 & Urt \\
\hline \multirow[t]{12}{*}{ Hypotrichida } & Aspidisca cicada & & & & + & + & & 5.5 & Asc \\
\hline & A. lynceus & & + & & & & & 1.4 & - \\
\hline & Euplotes sp. & + & & & & & & 2.8 & Eup \\
\hline & Holosticha sp. & + & + & & + & + & + & 21 & $\mathrm{Hsp}$ \\
\hline & Oxytricha haematoplasma & + & & & & & & 1.4 & - \\
\hline & O. setigera & & & + & & & + & 1.4 & - \\
\hline & Oxytricha sp. & + & + & + & + & + & + & 26.4 & Oxy \\
\hline & Pattersoniella vitiphila & + & + & + & + & + & + & 25 & Pav \\
\hline & Sterkiella histriomuscorum & + & + & + & + & & + & 14 & Sth \\
\hline & Stylonychia mytilus & + & + & + & + & + & & 14 & Stm \\
\hline & Uroleptus sp. & + & + & & + & + & & 14 & Uro \\
\hline & Unidentified Hypotrichida & + & & + & + & + & + & 34.8 & Hyp \\
\hline Karyorelictida & Loxodes sp. & + & + & & + & & & 2.8 & Lox \\
\hline \multirow[t]{6}{*}{ Nassulida } & Chilodontopsis depressa & + & & & + & + & + & 5.5 & Chd \\
\hline & Drepanomonas revoluta & + & + & + & & & + & 26.4 & Drr \\
\hline & Leptopharynx costatus & + & + & + & & & + & 13.4 & Lec \\
\hline & Microthorax pusillus & + & + & + & + & + & + & 44.4 & Mip \\
\hline & Nassula picta & & + & & & & & 1.4 & - \\
\hline & Pseudomicrothorax agilis & + & + & & & & & 7 & Psm \\
\hline \multirow[t]{2}{*}{ Odontostomatida } & Discomorphella pectinata & & + & & & & & 1.4 & - \\
\hline & Saprodinium dentatum & + & & & & & & 1.4 & - \\
\hline \multirow[t]{2}{*}{ Oligotrichida } & Halteria grandinella & + & + & + & + & + & + & 61 & Hag \\
\hline & Rimostrombidium humile & & & + & & & & 1.4 & - \\
\hline \multirow[t]{6}{*}{ Peritrichida } & Campanella umbellaria & + & & & & & & 2.8 & Cau \\
\hline & Epistylis sp. & & & + & & & & 1.4 & - \\
\hline & Opercularia sp. & & & & + & & + & 2.8 & - \\
\hline & Rhabdostyla sp. & & & & + & & & 1.4 & - \\
\hline & Vorticella aquadulcis & + & & & & + & + & 12.5 & Voa \\
\hline & Vorticella sp. & + & + & + & + & + & + & 23.6 & Vor \\
\hline \multirow[t]{3}{*}{ Pleurostomatida } & Acineria uncinata & + & + & + & & & & 5.5 & $\mathrm{Acu}$ \\
\hline & Litonotus crystallinus & & + & & & & & 1.4 & - \\
\hline & Litonotus varsaviensis & & + & + & & & & 2.8 & Liv \\
\hline \multirow[t]{7}{*}{ Prostomatida } & Bursellopsis spumosa & + & & & & & & 1.4 & - \\
\hline & Coleps hirtus & + & & & & & & 1.4 & - \\
\hline & Holophrya sp. & + & & + & + & + & & 5.5 & $\mathrm{Hol}$ \\
\hline & Holophrya teres & & & + & & & & 1.4 & - \\
\hline & Plagiocampa rouxi & & & & + & & + & 4.2 & Plr \\
\hline & Urotricha farcta & + & & & & & & 1.4 & - \\
\hline & Urotricha sp. & & + & & & & & 1.4 & - \\
\hline
\end{tabular}


Table 1 Occurrence and frequency of ciliate species recorded during both hydrological periods in the different strata (Continued)

\begin{tabular}{|c|c|c|c|c|c|c|c|c|c|}
\hline \multirow[t]{6}{*}{ Scuticociliatida } & Calyptotricha lanuginosa & + & + & + & & & & 14 & Cal \\
\hline & Cinetochilum margaritaceum & + & + & + & + & + & & 33.3 & Cim \\
\hline & Ctedoctema acanthocryptum & + & + & & & & + & 4.1 & Cta \\
\hline & Cyclidium glaucoma & + & + & + & + & + & + & 47.2 & Cyg \\
\hline & Cyclidium heptatrichum & + & + & + & + & + & + & 33.3 & Cyh \\
\hline & Pleuronema cf. smalli & + & & & & & & 2.8 & Pls \\
\hline
\end{tabular}

Cod = codes used in the DCA analysis; Freq $\%=$ frequency of ciliate species in percentage of samples; Low = lower stratum; Mid = middle stratum; Upp = upper stratum. For authorship and dates of names, see Foissner and Berger (1996); ${ }^{1}$ Foissner 2010; ${ }^{2}$ Foissner $2003 a ;{ }^{3}$ Foissner $2003 b$.

Opercularia sp., Spathidium sp.1, and Trochilioides recta characterize the rainy period (Figure $5 \mathrm{~B}$ ).

Spatially, the DCA show that only the samples of the lower stratum in the dry period have a visual separation from the others. The distance between the sampled bromeliad and the river seems to influence the ciliate species composition in the phytotelmata of the plants
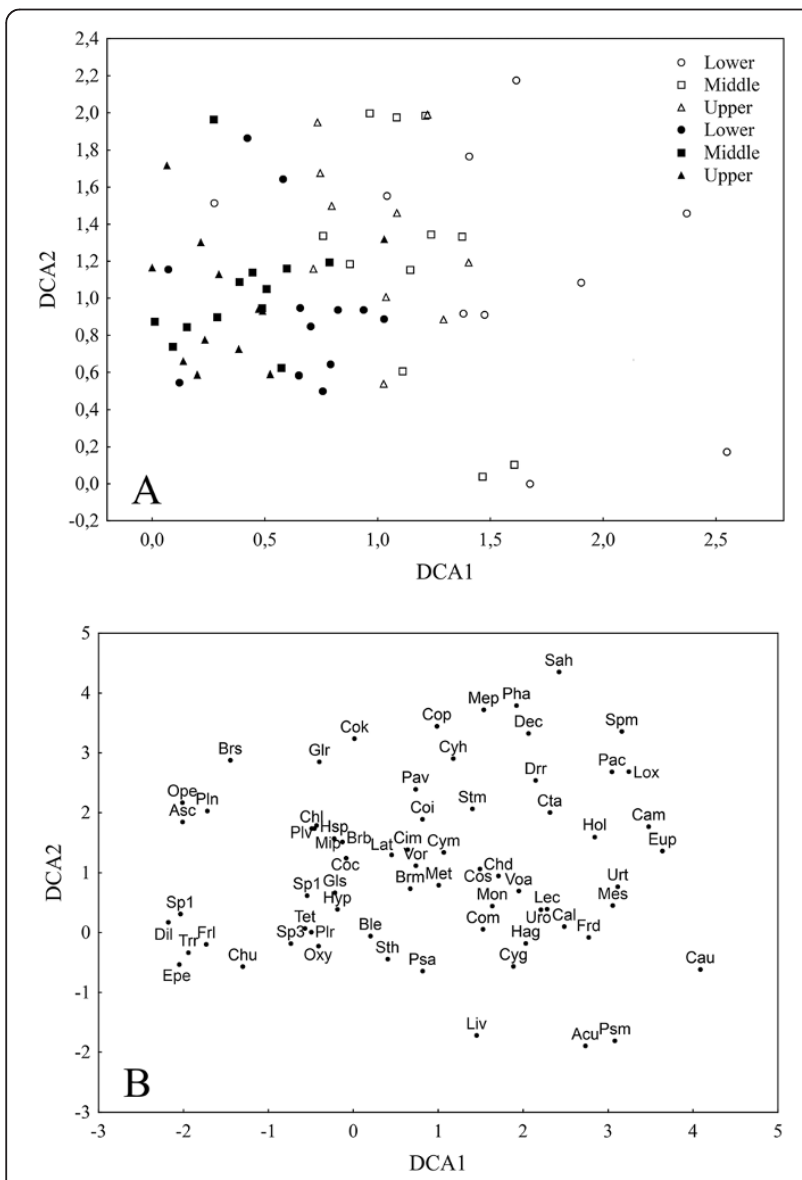

Figure 5 Ordination diagrams of the two first axes of the detrended correspondence analysis (DCA). (A) Ordination based on the eigenvalues of the strata and periods. The filled markers represent samples from the rainy period and the empty markers represent the dry period. (B) Ordination based on the eigenvalues of the ciliate species. Codes for the species are shown in the Table 1. only in the lower locations of the rocky wall, suggesting that the ciliate community of the plants in the lower stratum is strongly influenced by its proximity to the river.

A multi-response permutation procedure (MRPP) was performed for testing only the temporal differences in the ciliate species composition since the DCA results evidenced poorly representative spatial differences. Thus, the samples for the MRPP analysis were divided in two groups: (i) samples from the rainy period and (ii) samples from the dry period. According to the results, the ciliate species composition differed significantly between hydrological periods $(A=0.003 ; T=-17.53 ; p=0.00001)$.

\section{Discussion}

We recorded in the present study a total of 92 ciliate taxa inhabiting the tanks of the bromeliad $A$. distichantha. The small difference between the number of observed species (92 species) in relation to those estimated by the nonparametric extrapolating indices (between 102 and 128 species) evidenced that the sampling effort applied to this study was enough to make an efficient estimative number of ciliate species dwelling in the phytotelmata of this bromeliad in the study area.

The scarcity of ecological studies addressing the ciliated protozoa in these microenvironments does not allow us to make enlightening comparisons. Most of the research developed on phytotelmata emphasizes macro-organisms like insect larvae, arachnids, oligochaetes, and amphibians (Thienemann 1934; Inger 1966; Torales et al. 1972; Frank et al. 1976; Little and Hebert 1996; Reid and Janetsky 1996; Sodré et al. 2010; Suárez-Morales et al. 2010) with little attention to the microorganisms composing this microhabitat. Recent studies on ciliates inhabiting bromeliads' phytotelmata are focused on taxonomic aspects, describing a great number of new genera and species (Foissner 2003a, b, Foissner and Wolf 2009, Foissner et al. 2009, Foissner 2010, Foissner and Stoeck 2011, Dunthorn et al. 2012, Foissner 2013), but neglecting the ecological relationships of these organism with their environment. Until now, only few studies had an ecological approach (Foissner et al. 2003; Srivastava and Bell 2009, Weisse et al. 2013a, b). 
Foissner et al. (2003) combined in a study morphological and molecular data and ecological aspects of ciliated protozoa inhabiting tanks of bromeliads from South and Central America. In this study, the authors analyzed samples from 15 bromeliad species from Brazil, Ecuador, and Dominican Republic. A total of 48 ciliate taxa were recorded, of which approximately 15 would be new genera or species. Among all these recorded species, only 19 were found in bromeliads from Brazil. Despite the differences in sampling efforts between the two studies, our survey presents a high number of species when compared to those performed by Foissner et al. (2003).

This great discrepancy between the numbers of species of the two studies can be explained by the difference in the methodologies of the two investigations. The samples analyzed by Foissner et al. (2003) were collected in forest environments without any mention of bodies of water in the vicinity, while in the present study, the samples were collected in the left bank of a great river, which is a potential source of organisms for the phytotelmata. In this way, the number of planktonic species - probably originated from the river - in our samples were greater than that recorded by Foissner et al. (2003). This suggests that the proximity between the plants and the river is a keystone for the ciliate colonization in the phytotelmata present in the lower strata of the rocky wall.

Furthermore, the processing of the samples made by Foissner et al. (2003) might have influenced the lower number of species found by them. Most of the ecological data presented by the authors were based in analyses of species grown in culture mediums, and it is possible that this kind of analysis underestimate the real number of species in the samples. The authors transported and stored the samples for several days or even weeks, which could have contributed for the disappearance of several species. Samples in the present study were analysed in vivo within a maximum period of $6 \mathrm{~h}$ after sampling in order to avoid species losses and make a good estimation of the number of species.

The environment of the phytotelmata provides several niches for the ciliate species. Foissner et al. (2003) highlighted two main types of habitat for ciliates in a bromeliad's tank: (i) the water and the mud accumulated in the phytotelma, which provide niches for either planktonic and soil species and (ii) the body surface of small metazoans such as oligochaetes, chironomids, and ostracoda, in which some sessile peritrichs, or other ciliates are often found. We could observe in our survey a high occurrence and frequency of ciliate species commonly found in soils and some planktonic species, which corroborate the affirmation made by Foissner et al. (2003). However, only occasionally epibiont peritrichs were found in small metazoans. Often in plants with low water volume, there were large amounts of organic matter favoring the occurrence of soil species, like the Colpodids. On the other hand, when the water volume was larger, planktonic species were frequently found, such as the oligotrichid $H$. grandinella.

The high frequencies of occurrence of the colpodids $C$. steinii, C. inflata, C. cucculus, C. mucicola, and Platyophrya vorax, frequently abundant in soils of tropical environments as well (Lehle 1992; Aescht and Foissner 1993; Bamforth 1995, 2001, 2007; Foissner 1997a, b) suggest that the organic matter found in the tank bromeliads have a resemblance with that found in the neighboring soils. The colpodids find in the tanks a favorable environment for the establishment and development of their populations, since the organic matter accumulated in the phytotelmata mostly leaves and limbs from the canopy - is probably similar to the one that provides nutrients for the organisms in the soils.

Phytotelmata have been playing important roles in studies that aimed to understand the functioning of the food webs (Kitching 2000, 2001; Srivastava et al. 2004; Srivastava and Bell 2009; Brouard et al. 2012; Sabagh et al. 2012). These studies have described several types of food webs, with saprophagous, detritivorous, algivorous, fungivorous, and predatory organisms. It is believed that the presence of detritivorous organisms in the phytotelmata, specifically, provides an increase in the number of ciliate species. Srivastava and Bell (2009) state that some detritivorous insect larvae scrape and grind the greater debris particles making them thinner, which facilitate the decomposition process in the phytotelmata. In this way, the abundance of bacteria, and consequently the abundance of flagellates, will increase providing more food resources for the ciliates (Foissner and Wolf 2009).

High decomposition rates observed in the phytotelmata due to the presence of detritivorous species (Srivastava and Bell 2009) probably contribute to a decrease in the oxygen concentrations. These conditions favor the establishment and development of species characteristics of environments with low oxygen concentrations. Table 1 shows that the ciliate biota includes several obligate anaerobes such as representatives of the genera Caenomorpha, Saprodinium, Metopus, and Plagiopyla. According to Foissner and Berger (1996), these organisms are intolerant to even traces of oxygen. We thus believe that their presence demonstrate that anoxic conditions apparently develop in the phytotelmata of bromeliads and may open up for a new aspect of the microbial ecology of this particular environment.

Contrary to the expected, we recorded a significantly higher number of species in the dry period (74 species) when compared to the rainy season (58 species). Higher amounts of water during the rainy season would provide more spatial resources for the ciliate species decreasing 
the competition and the rate of extinction. Foissner et al. (2003) affirm that in the dry season, the low volume of water in the phytotelmata increases both intra- and interspecific competitions for space and resources. In these unfavorable conditions, several species encyst and few remain active; those that do not encyst and do not support the competition become extinct. Thus, the active diversity in dry periods would be substantially lower than in the rainy periods, in which there are hatching of cysts due to the favorable conditions. However, our results do not support this idea, and so we refuse the hypothesis (ii).

We were able to identify an interesting dynamics of some ciliate species during the data analyses. It is possible to see that some members of the ciliate community could reach the phytotelm but are not able to establish a persistent population. This is exemplified by the species that rarely occurred in our samples (Table 1). On the other hand, other species - the supposed endemic ones are probably present in the phytotelmata for the entire year, but only active during certain periods. In particular, it seems that many species may be excysting in response to greater concentration of organic matter and bacteria during dry periods - which would be usual for ciliates inhabiting ephemeral habitats. Hence, rather than describing the absolute community composition, our results showed the periodicity of some member of the ciliate community that persist year-round.

The Paraná River has its level frequently altered due to a reservoir of a hydroelectric power plant located upstream. Even in low water periods, the plants located at the lower stratum of the rocky wall are close to the river and it is possible that this proximity, be an important factor structuring the aquatic communities present in the phytotelmata. In this way, the frequencies of planktonic ciliate species in the bromeliads at the lower stratum, which have a greater influence of the river during the whole year, were high. Buosi et al. (2014) recorded, for the first time, the occurrence of Paramecium in the phytotelmata of bromeliads. They suggest that the species Paramecium multimicronucleatum - only observed in the plants located at the lower stratum - is dispersed from the littoral region of the Paraná River to the tanks of the bromeliads. This study emphasizes the importance of the river in structuring the ciliate communities of the plants closer to it.

By contrast, in the bromeliads at the upper stratum, high frequencies of species that are commonly found in soils were observed. These frequencies were higher in comparison to the plants at lower strata. This suggests that the surrounding soil is more important than the river in structuring the ciliate communities in the bromeliads at this location.

Thus, we can suggest that, in addition to rainfall, the proximity to the river plays an important role in determining the ciliate community composition in the bromeliads sampled in this study, probably facilitating the dispersion of organisms from the river to the plants. The results of the DCA show that the samples from the lower stratum, when the level of the river was high (first three samplings), are distinct from the others. On the other hand, when the level of the river was low (last three samplings), the ciliate species composition in the bromeliads at the lower stratum did not differ significantly from the others.

The results show that the rainfall strongly influenced the ciliate species composition associated to the phytotelmata of the bromeliad Aechmea distichantha, and constitutes an important factor in structuring the community, which corroborates our hypothesis (i). However, the results of the DCA did not evidence any influence of the height of the plants in relation to the river on the ciliate species composition, except for the plants at the lower stratum in the dry period. In this way, we refute the hypothesis (iii). These findings bring to light the need of new studies on the ciliate community inhabiting bromeliads phytotelmata, for a better understanding of the factors structuring the community.

\section{Conclusions}

This is one of the first studies approaching the ciliate community inhabiting the phytotelmata of the bromeliads in the riparian vegetation of the Paraná River. Thus, it is valid to emphasize that it is necessary to perform both experimental and in situ researches on the study area, so that the factors involved in the structuration of the ciliate community be completely elucidated. In the present study, we can conclude that, undoubtedly, the rainfall is the main factor in structuring the ciliate community inhabiting the bromeliads' phytotelmata. A clear distinctness was observed between the species composition in both hydrological periods. A high number of species was also recorded when compared to other studies on the ciliate community inhabiting phytotelmata. However, contrary to expected, the species number in the dry period was higher than in the rainy period. We suggest that this might be related to a dilution effect of the water held in the tanks provided by the greater amount of rainfall. Further, the increase in the concentration of organic matter and bacteria during dry periods may favor the excysting of some species, contributing to the higher number of species in the dry period. Finally, despite the occurrence of characteristic species in the different strata - planktonic species in the lower stratum and soil species in the medium and higher strata the DCA analysis shows no significant differences in the species composition among them. Nonetheless, the results suggest a great influence of the neighboring environments in the structuration of the ciliate community in the tank bromeliads, in view of the occurrence of similar species among the different environments. 


\section{Competing interests}

The authors declare that they have no competing interests.

\section{Authors' contributions}

LFMV, LRPU, and FALT are the mentors who wrote the original project and are responsible for the labs. PRBB, LRPU, LFMV, and FALT designed the study. PRBB, BRM, BTSS, and FMLT carried out the study as well as performed the statistical analyses. PRBB and LFMV made the figures and table and wrote the manuscript. LRPU commented, revised, and made remarkable contributions in the Discussion, enriching the manuscript. PRBB, LRPU, BRM, BTSS, FMLT, FALT, and LFMV finalized the manuscript. All authors read and approved the final manuscript.

\section{Acknowledgements}

This research was supported by PELD/CNPq and Nupélia/PEA/UEM. We thank CAPES and CNPq for fellowships to PRBB, BRM, BTSS, and FMLT. CNPq has continuously supported FALT and LFMV with grants. We also thank the two anonymous referees for their valuable contributions that enriched substantially our study.

\section{Author details}

${ }^{1}$ Graduate Program in Ecology of Continental Aquatic Environments, Universidade Estadual de Maringá, Av. Colombo, 5790, Maringá, Paraná 87020-900, Brazil. ªraduate Program in Zoology, Pontificia Universidade Católica do Rio Grande do Sul, Av. Ipiranga 6681, Porto Alegre, Rio Grande do Sul 90619-900, Brazil.

\section{Received: 19 March 2014 Accepted: 27 May 2014} Published: 28 June 2014

\section{References}

Aescht E, Foissner W (1993) Effects of organically enriched magnesite fertilizers on the soil ciliates of a spruce forest. Pedobiologia 38:321-335

Azoury R, Martinelli G (2000) Gefährdete Raritäten. Bromelien im Atlantischen Regenwald. Spektrum der Wissenschaft 6:66-73

Bamforth SS (1995) Interpreting soil ciliate biodiversity. Plant Soil 170:159-164

Bamforth SS (2001) Proportions of active ciliate taxa in soils. Biol Fertil Soils 33:197-203

Bamforth SS (2007) Protozoa from aboveground and ground soils of a tropical rain forest in Puerto Rico. Pedobiologia 50:515-525

Benzing BH (1990) Vascular epiphytes: general biology and related biota. Cambridge University Press, Cambridge

Brouard O, Céréghino R, Corbara B, Leroy C, Pelozuelo L, DeJean A, Carrias JF (2012) Understorey environments influence functional diversity in tankbromeliad ecosystems. Freshwater Biol 57:815-823

Buosi PRB, Cabral AF, Simão TLL, Utz LRP, Velho LFM (2014) Multiple lines of evidence shed light on the occurrence of Paramecium (Ciliophora, Oligohymenophorea) in bromeliad tank water. J Eukaryot Microbiol 61:2-10

Campos JB, Souza MC (1997) Vegetação. In: Vazzoler AEAM, Agostinho AA, Hahn NS (eds) A planície de inundação do alto rio Paraná: aspectos físicos, biológicos e socioeconômicos, 1st edn. Eduem, Maringá

Cowell RK (1997) EstimateS 5: statistical estimation species richness and shared species from samples. Version 5.0.1. University of Connecticut, Storrs, Available in http://www.viceroy.eeb.unconn.edu/estima-tes

Dragesco J, Dragesco-Kernéis A (1986) Ciliés libres de l'Afrique intertropicale. Introducion à la connaissance et à l'étude des ciliés. Faune Trop (Ėditions de l' ORSTOM) 26:1-559

Dunthorn M, Stoeck T, Wolf K, Breiner HW, Foissner W (2012) Diversity and endemism of ciliates inhabiting neotropical phytotelmata. Syst Biodivers 10:195-205

Finlay BJ, Corliss JO, Esteban GF, Fenchel T (1996) Biodiversity at the microbial level: the number of free-living ciliates in the biosphere. Q Rev Biol 71:221-237

Finlay BJ, Esteban GF, Fenchel T (2004) Protist diversity is different? Protist 155:15-22

Fish D (1983) Phytotelmata: terrestrial plants as hosts for aquatic insect communities. In: Frank JH, Lounibos LP (eds) Phytotelmata: flora and fauna. Plexus, New Jersey, pp 1-28

Foissner W (1997a) Soil ciliates (Protozoa: Ciliophora) from evergreen forests of Australia, South America and Costa Rica: diversity and description of new species. Biol Fertil Soils 25:317-339
Foissner W (1997b) Global soil ciliate (Protozoa, Ciliophora) diversity: a probability-based approach using large sample collections from Africa, Australia and Antarctica. Biodivers Conserv 6:1627-1638

Foissner W (2003a) Morphology and ontogenesis of Lambornella trichoglossa nov. spec., a new tetrahymenid ciliate (Protozoa, Ciliophora) from Brasilian tank bromeliads (Bromeliaceae). Eur J Protistol 39:63-82

Foissner W (2003b) Morphology and ontogenesis of Bromeliophrya brasiliensis gen. n., sp. n., a new ciliate (Protozoa: Ciliophora) from Brazilian tank bromeliads (Bromeliaceae). Acta Protozool 42:55-70

Foissner W (2010) Life cycle, morphology, ontogenesis, and phylogeny of Bromeliothrix metopoides, nov. gen., nov. spec., a peculiar ciliate (Protista, Colpodea) from tank bromeliads (Bromeliaceae). Acta Protozool 49:159-193

Foissner W (2013) Description of Glaucomides bromelicola n. gen., n. sp. (Ciliophora, Tetrahymenida), a macrostome forming inhabitant of bromeliads (Bromeliaceae), including redescriptions of Glaucoma scintillans and G. reniformis. J Eukaryot Microbiol 60:137-157

Foissner W, Berger H (1996) A user-friendly guide to the ciliates (Protozoa, Ciliophora) commonly used by hydrobiologists as bioindicators in rivers, lakes and waste waters, with notes on their ecology. Freshwater Biol 35:375-482

Foissner W, Stoeck T (2011) Cotterillia bromelicola nov. gen., nov. spec., a gonostomatid ciliate (Ciliophora, Hypotricha) from tank bromeliads (Bromeliaceae) with de novo originating dorsal kineties. Eur J Protistol 49:29-50

Foissner W, Wolf KW (2009) Morphology and ontogenesis of Platyophrya bromelicola nov. spec., a new macrostome-forming colpodid (Protists, Ciliophora) from tank bromeliads of Jamaica. Eur J Protistol 45:87-97

Foissner W, Blatterer H, Berger H, Kohmann F (1991) Taxonomische und ökologische Revision der Ciliaten des Saprobiensystems - Band I: Cyrtophorida, Oligotrichida, Hypotrichia, Colpodea. Informationsberichte des Bayer. Landesamtes für Wasserwirtschaft Heft 1(91):1-478

Foissner W, Berger H, Kohmann F (1992) Taxonomische und ökologische Revision der Ciliaten des Saprobiensystems - Band II: Peritrichia, Heterotrichida, Odontostomatida. Informationsberichte des Bayer. Landesamtes für Wasserwirtschaft Heft 5(92):1-502

Foissner W, Berger H, Kohmann F (1994) Taxonomische und ökologische Revision der Ciliaten des Saprobiensystems - Band III: Hymenostomata, Prostomatida, Nassulida. Informationsberichte des Bayerischen. Landesamtes für Wasserwirtschaft Heft 1(94):1-548

Foissner W, Blatterer H, Berger H, Kohmann F (1995) Taxonomische und ökologische Revision der Ciliaten des Saprobiensystems - Band IV: Gymnostomatea, Loxodes, Suctoria. Informationsberichte des Bayer. Landesamtes für Wasserwirtschaft Heft 1(95):1-540

Foissner W, Berger H, Schaumburg J (1999) Identification and ecology of limnetic plankton ciliates. Imformationsberichte des Bayer. Landesamtes Wasserwirtschaft Heft 3(99):1-793

Foissner W, Agatha S, Berger H (2002) Soil ciliates (Protozoa, Ciliophora) from Namibia (Southwest Africa), with emphasis on two contrasting environments, the tosha region and the Namib Desert. Denisia 5:1-1459

Foissner W, Strüder-Kypke M, van der Staay GWM, Moon-van der Staay SY, Hackstein JHP (2003) Endemic ciliates (Protozoa: Ciliophora) from tank bromeliads (Bromeliaceae): a combined morphological, molecular, and ecological study. Eur J Protistol 39:365-372

Foissner W, Blake N, Wolf K, Breiner HW, Stoeck T (2009) Morphological and molecular characterization of some peritrichs (Ciliophora: Peritrichida) from tank bromeliads, including two new genera: Orborhabdostyla and Vorticellides. Acta Protozool 48:291-319

Frank JH (1983) Bromeliad phytotelmata and their biota, especially mosquitoes. In: Frank JH, Lounibos LP (eds) Phytotelmata: terrestrial plants as host for aquatic insect communities. Plexus, Medford, New Jersey, pp 101-128

Frank JH, Curtis GA, Evans HJ (1976) On the bionomics of bromeliad inhabiting mosquitoes. II. The relationship of bromeliad size to the number of immature Wyeomyia vanduzeei and Wy. medioalbipes. Mosq News 37:180-192

Hill MO, Gauch HE (2004) Detrended correspondence analysis: an improved ordination technique. Plant Ecol 42:47-58

Inger RF (1966) The systematics and zoogeography of the Amphibia of Borneo. Fieldiana Zool 52:402-521

Kitching RL (2000) Food webs and container habitats: the natural history and ecology of Phytotelmata. Cambridge University Press, Cambridge

Kitching RL (2001) Food webs in phytotelmata: "Bottomup" and "top-down" explanations for community structure. Annu Rev Entomol 46:729-760

Laessle AM (1961) A micro-limnological study of Jamaican bromeliads. Ecology 42:499-517 
Lehle E (1992) Wimpertiere und andere Einzeller im Boden eines Fichtenbestandes im Schwarzwald. Mikrokosmos 81:193-198

Little TJ, Hebert PDN (1996) Endemism and ecological islands: the ostracods from Jamaican bromeliads. Freshw Biol 36:327-338

Lopez LCS, Alves RRN, Rios RI (2009) Micro environmental factors and the endemism of bromeliad aquatic fauna. Hydrobiologia 625:151-156

Maguire B Jr (1971) Phytotelmata: biota and community structure determination in plant-held waters. Annu Rev Ecol Syst 2:439-464

Maguire B Jr, Belk D (1967) Paramecium transport by land snails. J Protozool 14:445-447

McCune B, Mefford MJ (1999) Multivariate analysis of ecological data version 4.01. PC-ORD for Windows. MjM Software, Oregon

Ngai JT, Srivastava DS (2006) Predators accelerate nutrient cycling in a bromeliad ecosystem. Science 314:963-963

Patterson DJ (1992) Free-living freshwater protozoa - a color guide. CRC Press, Florida

Picado C (1912) Les maires aeriennes de la forêt vièrges américaine: les bromeliacées. Biologica 11:110-115

Picado C (1913) Les broméliacees épiphytes. Considerées comme milieu biologique. Bull Scient Fr Belg 47:215-360

Reid JW, Janetsky W (1996) Colonisation of Jamaican bromeliads by Tropocyclops jamaicensis n. sp. (Crustacea: Copepoda: Calanoidea). Invertebr Biol 115:305-320

Sabagh LT, Ferreira GL, Branco CWC, Rocha CFD, Dias NYN (2012) Larval diet in bromeliad pools: a case study of tadpoles of two species in the genus Scinax (Hylidae). Copeia 4:683-689

Schönborn W (2003) Lehrbuch der Limnologie. Schweitzerbart, Stuttgart

Smith LB, Downs RJ (1979) Bromelioideae (Bromeliaceae). Flora Neotropica $14: 1493-2142$

Sodré VM, Rocha O, Messias MC (2010) Chironomid larvae inhabiting bromeliad phytotelmata in a fragment of the Atlantic Rainforest in the Rio de Janeiro State. Braz J Biol 70:587-592

Souza Filho EE, Stevaux JC (2004) Geomorphology of the Paraná River Floodplain in the reach between the Paranapanema and Ivaí Rivers. In: Agostinho AA, Rodrigues L, Gomes LC, Thomaz SM, Miranda LE (eds) Structure and functioning of the Paraná River and its flooplain. Eduem, Maringá, pp 9-13

Souza MC, Romagnolo MB, Kita KK (2004) Riparian vegetation: ecotones and plant communities. In: Thomaz SM, Agostinho AA, Hahn NS (eds) The Upper Paraná River and its Floodplain. Backhuys, Leiden, pp 353-367

Srivastava DS, Bell T (2009) Reducing horizontal and vertical diversity in a foodweb triggers extinctions and impacts functions. Ecol Lett 12:1016-1028

Srivastava DS, Kolasa J, Bengtsson J, Gonzalez A, Lawler SP, Miller TE, Munguia P, Romanuk T, Schneider DC, Trzcinski MK (2004) Are natural microcosms useful model systems for ecology? Trends Ecol Evol 19:379-384

Suárez-Morales E, Mendoza F, Mercado-Salas N (2010) A new Allocyclops (Crustacea, Copepoda, Cyclopoida) from bromeliads and records of freshwater copepods from Mexico. Zoosystema 32:393-407

Thienemann A (1934) Der tierwelt der tropischen Planzengewässer. Arch Hydrobiol Suppl 13:1-91

Torales GC, Hack WH, Turn B (1972) Criaderos de culicídeos en bromeliáceas del NW de Corrientes. Acta Zool Lillo 29:293-308

Vandermeer J, Addicott J, Andersen A, Kitasako J, Pearson D, Schnell C, Wilbur H (1972) Observations on Paramecium occupying arboreal standing water in Costa Rica. Ecology 53:291-293

Weisse T, Scheffel U, Stadler P, Foissner W (2013a) Bromeliothrix metopoides, a boom and bust ciliate (Ciliophora, Colpodea) from tank bromeliads. Eur J Protistol 49:406-419

Weisse T, Scheffel U, Stadler P, Foissner W (2013b) Functional ecology of the ciliate Glaucomides bromelicola, and comparison with the sympatric species Bromeliothrix metopoides. J Eukaryot Microbiol 60:578-587

Zimmerman GM, Goetz H, Mielke PW Jr (1985) Use of an improved statistical method for group comparisons to study effects of prairie fire. Ecology 66:606-611

\section{doi:10.1186/s40555-014-0032-4}

Cite this article as: Buosi et al:: Rainfall influence on species composition of the ciliate community inhabiting bromeliad phytotelmata. Zoological Studies 2014 53:32 